\title{
The Ascent of F6: Exceptional Collaborative Case in Poetic Drama
}

\author{
Yahya Saleh Hassan Dahami \\ Department of English \\ Faculty of Science \& Arts, Al Baha University \\ Al Mandaq, Saudi Arabia
}

\begin{abstract}
To write plays are not easy, to make them verse, is difficult but to cooperate in composing poetic drama, is of great challenge. This study tries to prove the capability and manageability in collaboration not only in ordinary prose drama but also in poetic plays. It aims to trace, through an analytical and critical technique, the procedures of collaboration showing, to what degree both of the two collaborators, Auden and Isherwood, achieved success in dealing with contemporary poetic drama using modern language. The research is an approach on one of the likely best plays they shared, The Ascent of F6 (1933). The study starts giving a glance on poetic drama then it traces the collaboration between W. H. Auden and Christopher Isherwood with special reference to the poetic play The Ascent of F6.
\end{abstract}

Key Words: Auden and Isherwood, collaboration, plays, poetic drama, twentieth century

Cite as: Dahami, Y. S.H. (2018). The Ascent of F6: Exceptional Collaborative Case in Poetic Drama. Arab World English Journal for Translation \& Literary Studies, 2 (2).

DOI: http://dx.doi.org/10.24093/awejtls/vol2no2.11 